\title{
IMPROVING STRESS RUPTLRE LIFE OF ALLOY 718 BY OPTIMIZING AL, TI, P AND B CONTENTS
}

\author{
W. D. Cao and R. L. Kennedy \\ Allvac, An Allegheny Technologies Company \\ 2020 Ashcraft Avenue \\ Monroe, North Carolina 28110
}

\begin{abstract}
An attempt was made to combine the beneficial effects of $\mathrm{P}$ and $\mathrm{B}$ with modifications of $\mathrm{Al}$. Ti and $\mathrm{Nb}$ to improve stress rupture properties of alloy 718. Three versions of $\mathrm{Al}$, $\mathrm{Ti}$ and $\mathrm{Nb}$ modifications suggested in the literature; 718Ti/Al with higher $\mathrm{Ti}$ and $\mathrm{Al}(1.35 \mathrm{Ti}, 0.65 \mathrm{Al})$, Ticolloy with higher $\mathrm{Al}(1.0 \mathrm{Ti}, 1.0 \mathrm{Al})$ and alloy $718 \mathrm{CM}$ with compact morphology of $y^{*}$ and $\gamma^{*}$ $(1.25 \mathrm{Ti}, 1.10 \mathrm{Al} .5 .0 \mathrm{Nb})$ were selected for investigation. Standard $718(1.0 \mathrm{Ti}, 0.5 \mathrm{Al})$ was also made as a base for comparison. Each group of alloys was melted at three $\mathrm{P}$ and $\mathrm{B}$ levels: $(0.006 \mathrm{P}, 0.004 \mathrm{~B}),(0.002 \mathrm{P}, 0.004 \mathrm{~B})$ and $(0.020 \mathrm{P}, 0.010 \mathrm{~B})$. Mechanical properties of each alloy, including tensile at room and elevated temperature and stress rupture propertics, were determined.

The results from standard alloys confirmed previous studies. The increased $P$ and $B$ led to a 60 to $90 \%$ improvement in stress rupture life with tensile strength being unchanged. The effect of modified strengthening elements on mechanical properties at standard $\mathrm{P}$ and $\mathrm{B}$ level was consistent with data published in the literature. Stress rupture life of alloy 718 was moderately increased by strengthening element modifications in the standard heat treatment condition. Tensile strength was generally not affected or slightly reduced. The principal effect of modified strengthening elements was to increase thermal stability. Combining high $\mathrm{P}$ and $\mathrm{B}$ levels with $\mathrm{Al}$, Ti and $\mathrm{Nb}$ moditications resulted in a further improvement in stress rupture properties and this improvement was maintained to higher temperature and after long time thermal exposure. Alloy $718 \mathrm{CM}$ with increased $\mathrm{P}$ and $\mathrm{B}$ levels showed the best results. Combining the modifications used in this study moderately improved the temperature capability of alloy 718 .
\end{abstract}

Superallog: 718.625 .706 and Various Derivatives

Edited by E.A. Loria

TMS (The Mintrals. Wetals \& Materials Socicty). 2001 


\section{Introduction}

Many attempts have been made to improve the elevated temperature properties of alloy 718 by chemistry modification, including changes in both major and minor chemical elements.

Previous studies by the authors [1-5] have demonstrated that the minor element $P$ has a dramatic effect on the elevated temperature creep and stress rupture properties of alloy 718 . As shown in [1], increasing $P$ from about $0.006 \%$, typical of standard commercial 718 , to $0.02 \%$ can result in nearly a $100 \%$ increase in stress rupture life at $650^{\circ} \mathrm{C}$. The positive effect of increased $P$ contents has been supported by many subsequent studies [6-11]. It has also been shown [2.3] that there is a synergic effect between $\mathrm{P}$ and $\mathrm{B}$, and increased $\mathrm{P}$ combined with increased $\mathrm{B}$ can further improve creep and stress rupture properties of alloy 718 . Low $\mathrm{C}$ in combination with increased $\mathrm{P}$ and $\mathrm{B}$ contents can increase stress rupture life at $650^{\circ} \mathrm{C}$ by as much as $200-300 \%$ at the optimum combination of $0.022 \% \mathrm{P}, 0.011 \% \mathrm{~B}$ and $0.005 \% \mathrm{C}$. A similar synergic effect of $\mathrm{P}$ and $B$ applies to creep properties of alloy $718[5,12,13]$. However, recent work [14] has shown that the $\mathrm{P}$ and $\mathrm{B}$ modification does not noticeably improve the thermal stability of alloy 718 , and that the improvement in creep and stress rupture properties diminished with increasing test temperature and after long time thermal exposure at elevated temperature.

Many attempts have been made to modify the major strengthening elements $\mathrm{Nb}$, $\mathrm{Ti}$ and $\mathrm{Al}$ in alloy 718 to improve its performance at elevated temperature. One approach has been to increase $\mathrm{Al} / \mathrm{Ti}$ ratio and/or $(\mathrm{Al}+\mathrm{Ti}) / \mathrm{Nb}$ ratio to reduce the coarsening rate of $\gamma$ " particles and to retard the formation of $\delta$ phase at elevated temperatures [15-18]. This direction led to the development of Ticolloy containing about $1 \% \mathrm{Al}$ and $1 \% \mathrm{Ti}[17,18]$. Another idea was to closely control the $(\mathrm{Al}+\mathrm{Ti}) / \mathrm{Nb}$ ratio and the $(\mathrm{Al}+\mathrm{Ti}+\mathrm{Nb})$ sum such that a specific $\gamma^{\circ}+\gamma^{\prime \prime}$ microstructure. termed "compact morphology". was achieved [19-21]. This consisted of cube-shaped $\gamma^{\prime}$ particles coated with a shell of $\gamma^{\prime \prime}$ precipitates which were very stable at elevated temperatures. The mechanical properties of alloy 718 with modified $\mathrm{Al}$, Ti and $\mathrm{Nb}$ contents have been evaluated in a number of additional studies [22-26]. The improvement in elevated temperature properties was relatively small, especially after taking grain size effects into account. The increase in stress rupture life was less than $25 \%$ in most cases. However, the thermal stability of alloys did increase, as shown by less reduction in stress rupture life after long time heating at elevated temperatures.

A natural development for further improving elevated temperature properties of alloy 718 would be to combine both the major and minor element approaches. The goal would be to maintain the improvement in creep and stress rupture properties from $\mathrm{P}$ and $\mathrm{B}$ modification to higher temperature by virtue of $\mathrm{Al}$, $\mathrm{Ti}$ and $\mathrm{Nb}$ modifications and, therefore, increase the temperature capability of alloy 718 . This paper will report the results of research performed at Allvac along this direction.

\section{Experimental Procedures}

\section{Test Materials and Processing}

Chemistries of the alloys prepared for this study are listed in Table I. All were basically identical except for strengthening elements ( $\mathrm{Al}, \mathrm{Ti}$ and sometimes $\mathrm{Nb}$ ), and minor elements ( $\mathrm{P}$ and $\mathrm{B}$ and in one case $\mathrm{C}$ ). The alloys were divided into four groups on the basis of Al, Ti and Nb levels: standard 718 with $1.0 \% \mathrm{Ti}, 0.5 \% \mathrm{Al}$ (group 1). $718 \mathrm{Ti} / \mathrm{Al}$ with $1.35 \% \mathrm{Ti}, 0.65 \% \mathrm{Al}$ (group 2). Ticolloy with $1.0 \% \mathrm{Ti}, 1.0 \% \mathrm{Al}$ (group 3) and 718CM (compact morphology) with 
$1.25 \% \mathrm{Ti}, 1.1 \% \mathrm{Al}, 5.0 \% \mathrm{Nb}$ (group 4). Three $\mathrm{P}$ and $\mathrm{B}$ levels were produced in each group. The $0.008 \% \mathrm{P}, 0.005 \% \mathrm{~B}$ levels are close to $\mathrm{P}$ and $\mathrm{B}$ contents of commercial 718 . Increased $\mathrm{P}$ and $\mathrm{B}$ levels $(0.020 \% \mathrm{P}, 0.010 \% \mathrm{~B})$ have been shown to achieve optimum creep-stress rupture properties in standard 718 . Alloys with $0.002 \% \mathrm{P}$ were included to show the effect of low P content.

Table I. Chemistries of Test Alloys with Modified Al, Ti, P and B

\begin{tabular}{|c|c|c|c|c|c|c|c|c|c|c|}
\hline \multirow{2}{*}{$\begin{array}{l}\text { Heat } \\
\text { No. }\end{array}$} & \multicolumn{10}{|c|}{ Chemistry (wt.\%) } \\
\hline & $\mathrm{C}$ & Mo & $\mathrm{Cr}$ & $\mathrm{Fe}$ & $\mathrm{Nb}$ & $\mathrm{Ti}$ & $\mathrm{Al}$ & Mg & $\mathrm{P}^{*}$ & $\mathrm{~B}^{*}$ \\
\hline \multicolumn{11}{|c|}{ Group 1: Standard $718(0.5 \% \mathrm{Al}+1.0 \% \mathrm{Ti})$} \\
\hline WD83 & 0.028 & 2.87 & 17.9 & 18.1 & 5.45 & 1.00 & 0.53 & 10 & 20 & 37 \\
\hline WE87 & 0.031 & 2.90 & 17.8 & 18.1 & 5.47 & 0.99 & 0.52 & 14 & 80 & 60 \\
\hline WD84 & 0.032 & 2.88 & 17.9 & 18.0 & 5.47 & 1.00 & .0050 & 10 & 200 & 103 \\
\hline WE9l & 0.006 & 2.89 & 17.8 & 18.1 & 5.46 & 1.00 & 0.54 & 14 & 210 & 100 \\
\hline \multicolumn{11}{|c|}{ Group 2: $718 \mathrm{Ti} / \mathrm{Al}(0.65 \% \mathrm{Al}+1.35 \% \mathrm{Ti})$} \\
\hline WD86 & 0.027 & 2.88 & 17.9 & 17.9 & 5.45 & 1.35 & 0.65 & 12 & 20 & 31 \\
\hline WE89 & 0.028 & 2.88 & 17.8 & 17.7 & 5.46 & 1.34 & 0.69 & 18 & 90 & 50 \\
\hline WD85 & 0.030 & 2.87 & 17.9 & 17.8 & 5.44 & 1.35 & 0.66 & 15 & 200 & 100 \\
\hline \multicolumn{11}{|c|}{ Group 3: Ticolloy $(1.0 \% \mathrm{AI}+1.0 \% \mathrm{Ti})$} \\
\hline WD91 & 0.028 & 2.90 & 18.0 & 17.9 & 5.51 & 1.01 & 0.96 & 16 & 20 & 36 \\
\hline WE88 & 0.033 & 2.88 & 17.9 & 17.8 & 5.42 & 1.00 & 0.98 & 16 & 80 & 50 \\
\hline WD88 & 0.026 & 2.90 & 17.9 & 17.9 & 5.49 & 1.00 & 0.94 & 16 & 210 & 114 \\
\hline \multicolumn{11}{|c|}{ Group 4: $718 \mathrm{CM}(1.10 \% \mathrm{Al}+1.25 \% \mathrm{Ti})$} \\
\hline WD90 & 0.028 & 2.89 & 18.0 & 18.0 & 4.95 & 1.23 & 1.09 & 23 & 20 & 35 \\
\hline WG45 & 0.027 & 2.91 & 18.0 & 17.9 & 5.08 & 1.24 & 1.09 & 19 & 80 & 50 \\
\hline WD89 & 0.028 & 2.90 & 18.0 & 18.0 & 5.01 & 1.24 & 1.11 & 17 & 210 & 102 \\
\hline
\end{tabular}

The melting and hot working of test alloys were the same as those used in previous studies [1-5]. Briefly, all were vacuum induction melted (VIM) and vacuum are re-melted (VAR) to $100 \mathrm{~mm}$ diameter ingots with a weight of $23 \mathrm{Kg}$. Ingots were homogenized for $16 \mathrm{hrs}$. and rolled to 15 $\mathrm{mm}$ diameter bars within a temperature range of $1040^{\circ} \mathrm{C}$ to $920^{\circ} \mathrm{C}$.

All alloys were subjected to the solution heat treatment of $954^{\circ} \mathrm{C} \times 1 \mathrm{hr}$.. air cooled and then aged at $718^{\circ} \mathrm{C}$ x $8 \mathrm{hrs}$. furnace cooled at $55^{\circ} \mathrm{C} / \mathrm{hr}$. to $621^{\circ} \mathrm{C}$. held for $8 \mathrm{hrs}$., air cooled. typical for standard 718. Modified heat treatments suggested in the literature $[18,26]$ to fully utilize the beneficial effect of modified strengthening elements were also used. Alloys Ticolloy and $718 \mathrm{Ti} / \mathrm{Al}$ were heat treated at $982^{\circ} \mathrm{C} \times 1 \mathrm{hr}$. solution, air cooled and then aged for $8 \mathrm{hrs}$. at $760^{\circ} \mathrm{C}$. furnace cooled at $55^{\circ} \mathrm{C} / \mathrm{hr}$. to $649^{\circ} \mathrm{C}$. held for $8 \mathrm{hrs}$. air cooled. For $718 \mathrm{CM}$. the modified heat treatment was $982^{\circ} \mathrm{C} \times 1 \mathrm{hr}$. solution, air cooled and then aged for $1 / 2 \mathrm{hr}$. at $850^{\circ} \mathrm{C}$. furnace cooled at $200^{\circ} \mathrm{C} / \mathrm{hr}$. to $649^{\circ} \mathrm{C}$. held for $16 \mathrm{hrs}$. air cooled. Alloy 718 was also tested with a $982{ }^{\circ} \mathrm{C}$ solution + standard age treatment to determine the effect of chemistry modifications without the interference of grain size differences. Samples subjected to the modificd heat treatments were further heat treated at $704^{\circ} \mathrm{C}$ for 1000 hrs. to evaluate thermal stability.

\section{Mechanical Tests}

Two slightly different series of mechanical tests were carried out on the two different heat treatment conditions: room temperature tensile. $649^{\circ} \mathrm{C}$ tensile, and stress rupture tests at $649^{\circ} \mathrm{C} /$ 
$669 \mathrm{MPa}$ and $649^{\circ} \mathrm{C} / 773 \mathrm{MPa}$ on alloys subjected to the standard heat treatment: room temperature tensile. $649^{\circ} \mathrm{C}$ tensile and stress rupture tests at $677^{\circ} \mathrm{C} / 690 \mathrm{MPa}$ and $704^{\circ} \mathrm{C} / 621 \mathrm{MPa}$ on alloys given the modified heat treatments. This latter series of tests was performed on samples, both as-heat treated and after $1000 \mathrm{hrs}$. exposure at $704^{\circ} \mathrm{C}$. Higher test temperatures were used in this second series of tests to better evaluate the temperature capability of alloy 718 with modified chemistries. All test results represent the average of at least two tests.

\section{Microstructures}

Microstructures after different heat treatments were examined by optical and scanning electron microscope (SEM). No attempt was made to characterize the precipitates by transmission electron microscope (TEM) since this work had been performed in detail by other researchers. Emphasis was placed on the study of grain size, $\delta$ phase particles and microstructure after $704^{\circ} \mathrm{C} \times 1000$ hrs. thermal exposure. The chemistry of relevant microstructural constituents was analyzed by energy disperse X-ray spectrum (EDS).

\section{Results}

\section{$\underline{\text { Standard Heat Treatment }}$}

Table II summarizes mechanical property results for alloys subject to the standard 718 heat treatment. The effect of $\mathrm{P}$ and $\mathrm{B}$ modification on mechanical properties of alloy 718 can be seen from the results of Group 1 alloys in this table. Consistent with previous studies $[1-5]$. increasing $\mathrm{P}$ and $\mathrm{B}$ to $0.02 \%$ and $0.01 \%$, respectively increased stress rupture life by 60 to $90 \%$. High $\mathrm{P}$ and $\mathrm{B}$ in conjunction with low $\mathrm{C}(0.006 \%)$ further increased the stress rupture life to 140 to $170 \%$ greater than standard 718 . The stress rupture life was the lowest when $P$ was reduced to a very low level $(0.02 \%)$, below the amount present in typical commercial 718. The $\mathrm{P}$ and $\mathrm{B}$ level had minor effects on tensile properties. Consistent $\mathrm{P}$ and $\mathrm{B}$ effects were seen in the other alloy groups, but to a lesser extent.

The effect of $\mathrm{Al}$. Ti and $\mathrm{Nb}$ modifications on mechanical properties can also be seen from Table II by comparing heats with similar $\mathrm{P}$ and $\mathrm{B}$ contents from each of the four alloy groups. While the data was somewhat inconsistent, Group 2 (718Ti/Al) and Group 3 (Ticolloy) alloys appeared to have slightly improved stress rupture life compared to standard 718. The degree of improvement due to $\mathrm{Al}$, $\mathrm{Ti}$ and $\mathrm{Nb}$ changes was smaller than that associated with $\mathrm{P}$ and $\mathrm{B}$ except for the alloys with the very low $\mathrm{P}$ and $\mathrm{B}$ content. As was the case with the standard 718 compositions, rupture lives for all of the modified compositions were the lowest, by a significant amount, at the lowest P levels. The data further suggest that the improvement in rupture life due to major strengthening element changes was closely related to the $\mathrm{P}$ and $\mathrm{B}$ level of the alloys. The greatest relative improvements were seen in alloys with very low $P$ content and decreased with increasing $P$ and $B$ levels. The effect of $\mathrm{P}$ and $\mathrm{B}$ on rupture lives was smaller in the $\mathrm{Al}$, Ti and $\mathrm{Nb}$ modified alloys than in standard 718. It was also apparent that there was no synergistic interaction between $P$ and $B$ and the major strengthening elements and that the latter did not make a signiticant contribution to improvement in stress rupture properties of 718 with optimum $P$ and $B$ contents. 
Table II. Mechanical Properties of Test Alloys Subject to Standard Heat Treatment

\begin{tabular}{|c|c|c|c|c|c|c|c|c|c|c|c|c|}
\hline \multirow{3}{*}{$\begin{array}{c}\text { Heat } \\
\text { No. }\end{array}$} & \multicolumn{8}{|c|}{ Tensile Properties } & \multicolumn{4}{|c|}{ Stress Rupture } \\
\hline & \multicolumn{4}{|c|}{$20^{\circ} \mathrm{C}$} & \multicolumn{4}{|c|}{$650^{\circ} \mathrm{C}$} & \multicolumn{2}{|c|}{$\begin{array}{c}650^{\circ} \mathrm{C} \\
690 \mathrm{MPa}\end{array}$} & \multicolumn{2}{|c|}{$\begin{array}{c}650^{\circ} \mathrm{C} \\
772 \mathrm{MPa}\end{array}$} \\
\hline & $\begin{array}{l}\text { UTS } \\
\mathrm{MPa}\end{array}$ & $\begin{array}{c}\mathrm{YS} \\
\mathrm{MPa}\end{array}$ & $\begin{array}{l}\text { EL } \\
\%\end{array}$ & $\begin{array}{c}\text { RA } \\
\%\end{array}$ & $\begin{array}{l}\text { UTS } \\
\text { MPa }\end{array}$ & $\begin{array}{l}\mathrm{YS} \\
\mathrm{MPa}\end{array}$ & $\begin{array}{l}\mathrm{EL} \\
\%\end{array}$ & $\begin{array}{l}\text { RA } \\
\%\end{array}$ & $\begin{array}{l}\text { Life } \\
\text { Hrs }\end{array}$ & $\begin{array}{c}\text { EL } \\
\%\end{array}$ & $\begin{array}{l}\text { Life } \\
\text { Hrs }\end{array}$ & $\begin{array}{c}E L \\
\%\end{array}$ \\
\hline \multicolumn{13}{|c|}{ Group 1: Standard $718(0.5 \% \mathrm{Al}+1.0 \% \mathrm{Ti})$} \\
\hline WD83 & 1500 & 1195 & 25.0 & 39.2 & 1180 & 1005 & 36.5 & 73.2 & 37.6 & 29.5 & 16.0 & 28.5 \\
\hline WE87 & 1481 & 1203 & 22.9 & 41.0 & 1214 & 1045 & 28.6 & 66.7 & 179.3 & 29.3 & 52.3 & 26.6 \\
\hline WD84 & 1476 & 1180 & 24.5 & 40.1 & 1203 & 996 & 34.5 & 71.8 & 290.5 & 22.0 & 99.1 & 22.0 \\
\hline WE91 & 1482 & 1199 & 22.9 & 43.3 & 1182 & 992 & 34.0 & 62.9 & 484.0 & 18.2 & 142.2 & 24.7 \\
\hline \multicolumn{13}{|c|}{ Group 2: $718 \mathrm{Ti} / \mathrm{Al}(0.65 \% \mathrm{Al}+1.35 \% \mathrm{Ti})$} \\
\hline WD86 & 1524 & 1214 & 24.5 & 37.4 & 1180 & 986 & 27.5 & 41.2 & 70.3 & 35.5 & 24.7 & 29.0 \\
\hline WE89 & 1513 & 1199 & 27.1 & 39.9 & 1269 & 1065 & 27.4 & 65.7 & 241.4 & 28.4 & 79.4 & 30.0 \\
\hline WD85 & 1500 & 1187 & 24.0 & 37.7 & 1223 & 1003 & 37.5 & 64.3 & 375.6 & 23.0 & 81.3 & 21.5 \\
\hline \multicolumn{13}{|c|}{ Group 3: Ticolloy $(1.0 \% \mathrm{AI}+1.0 \% \mathrm{Ti})$} \\
\hline WD91 & 1504 & 1150 & 24.0 & 40.6 & 1193 & 1005 & 32.5 & 49.0 & 81.1 & 29.0 & 33.5 & 26.4 \\
\hline WE88 & 1513 & 1178 & 22.9 & 38.3 & 1218 & 1006 & 33.2 & 54.2 & 189.9 & 33.1 & 83.9 & 34.8 \\
\hline WD88 & 1516 & 1196 & 23.5 & 36.2 & 1233 & 1022 & 36.0 & 67.7 & 226.5 & 26.0 & 111.6 & 28.0 \\
\hline \multicolumn{13}{|c|}{ Group 4: $718 \mathrm{CM}(1.1 \% \mathrm{Al}+1.25 \% \mathrm{Ti})$} \\
\hline WD90 & 1515 & 1129 & 23.0 & 22.2 & 1213 & 946 & 37.0 & 67.8 & 52.1 & 35.5 & 24.4 & 34.5 \\
\hline WG45 & 1508 & 1174 & 24.9 & 39.0 & 1211 & 985 & 22.3 & 19.5 & 124.8 & 23.2 & 61.1 & 27.0 \\
\hline WD89 & 1526 & 1149 & 21.5 & 28.3 & 1247 & 963 & 34.5 & 61.9 & 199.1 & 25.0 & 110.9 & 32.6 \\
\hline
\end{tabular}

Note: Standard 718 heat treatment applied to all samples:

$954^{\circ} \mathrm{C} \times 1 \mathrm{hr}$. AC. $718^{\circ} \mathrm{C} \times 8$ hrs.. FC at $55^{\circ} \mathrm{C} / \mathrm{hr}$. to $621^{\circ} \mathrm{C} \times 8$ hrs.. AC

\section{Modified Heat Treatments}

The mechanical properties of test alloys subjected to modified heat treatments are listed in Tables III to VI. Several observations were made from these data:

1. Increasing $P$ and $B$ improved the stress rupture properties of all of the alloy groups except $718 \mathrm{Ti} / \mathrm{Al}$ without adversely affecting tensile properties. The degree of improvement appeared to be temperature-dependent and diminished with increasing test temperature. Relative improvements in stress rupture life were smallest at $704^{\circ} \mathrm{C}$. although all rupture times were very short because of the chosen test conditions. These results nevertheless agreed with earlier work [14], suggesting the strengthening effect of $\mathrm{P}$ and $\mathrm{B}$ modification diminished significantly at $704^{\circ} \mathrm{C}$ or higher. The same observation appeared to be true for the modified alloys studied in this work.

2. $\mathrm{Al}, \mathrm{Ti}$ and $\mathrm{Nb}$ chemistry modifications in the modified heat treat conditions appeared to have slightly reduced rupture lives compared to standard 718 and also seemed to influence the strengthening effect of $\mathrm{P}$ and $\mathrm{B}$ modification. The greatest, relative improvement in stress rupture life at $677^{\circ} \mathrm{C} / 690 \mathrm{MPa}$ due to increased $\mathrm{P}$ and $\mathrm{B}$ was observed in $718 \mathrm{CM}$. Tensile strength of $718 \mathrm{CM}$ alloys in the modified heat treat condition, however, was substantially below that of the other three alloys.

3. Strengthening element modifications had a noticeable effect on thermal stability of alloy 718. as measured by the ratio of stress rupture life after $704^{\circ} \mathrm{C} \times 1000$ hrs. thermal exposure to that in the as heat treated condition (retention ratio $\mathrm{R}_{\mathrm{T}}$ ). As shown in Tables III to VI, this ratio was about $0.10-0.20$ in alloy 718 . but increased to about $0.40-0.50$ in $718 \mathrm{CM}$ which showed the highest stability. The retention ratio was also improved in other modified alloys, but to a lesser degree. 
Table III. Effect of $704^{\circ} \mathrm{C} / 1000 \mathrm{hr}$ Thermal Exposure on Mechanical Properties of Standard 718 with Different $P+B$ Contents

\begin{tabular}{|c|c|c|c|c|c|c|c|c|c|c|c|c|}
\hline & \multicolumn{8}{|c|}{ Tensile Properties } & \multicolumn{4}{|c|}{ Stress Rupture } \\
\hline & \multicolumn{4}{|c|}{$20^{\circ} \mathrm{C}$} & \multicolumn{4}{|c|}{$650^{\circ} \mathrm{C}$} & \multicolumn{2}{|c|}{$\begin{array}{c}677^{\circ} \mathrm{C} \\
690 \mathrm{MPa}\end{array}$} & \multicolumn{2}{|c|}{$\begin{array}{c}704^{\circ} \mathrm{C} \\
621 \mathrm{MPa} \\
\end{array}$} \\
\hline & $\begin{array}{l}\text { LTS } \\
\mathrm{MPa}\end{array}$ & $\begin{array}{c}\mathrm{YS} \\
\mathrm{MPa}\end{array}$ & $\begin{array}{c}\mathrm{EL} \\
\%_{0}\end{array}$ & $\begin{array}{l}\mathrm{RA} \\
\%\end{array}$ & $\begin{array}{l}\text { UTS } \\
\mathrm{MPa}\end{array}$ & $\begin{array}{l}\mathrm{YS} \\
\mathrm{MPa}\end{array}$ & $\begin{array}{c}E L \\
\%\end{array}$ & $\begin{array}{l}\mathrm{RA} \\
\%\end{array}$ & $\begin{array}{l}\text { Life } \\
\text { Hrs }\end{array}$ & $\begin{array}{c}\mathrm{EL} \\
\%\end{array}$ & $\begin{array}{l}\text { Life } \\
\text { Hrs }\end{array}$ & $\begin{array}{c}\text { EL } \\
\%\end{array}$ \\
\hline \multicolumn{13}{|c|}{ WE87 $(0.008 \% \mathrm{P}+0.006 \% \mathrm{~B})$} \\
\hline $\begin{array}{l}\text { As-Heat } \\
\text { Treated }\end{array}$ & 1494 & 1249 & 24.1 & 43.6 & 1187 & 1031 & 29.3 & 40.6 & 30.5 & 41.6 & 13.1 & 43.1 \\
\hline $\begin{array}{c}704^{\circ} \mathrm{C} / \\
1000 \mathrm{hrs}\end{array}$ & 1367 & 1031 & 29.3 & 40.6 & 1035 & 878 & 33.9 & 73.5 & 4.1 & 40.3 & 2.3 & 39.0 \\
\hline$R_{T}$ & 0.91 & 0.83 & 1.22 & 0.93 & 0.87 & 0.85 & 1.16 & 1.81 & 0.13 & 0.97 & 0.16 & 0.90 \\
\hline \multicolumn{13}{|c|}{ WD84 $(0.020 \% \mathrm{P}+0.010 \% \mathrm{~B})$} \\
\hline $\begin{array}{l}\text { As-Heat } \\
\text { Treated }\end{array}$ & 1475 & 1206 & 23.7 & 39.2 & 1180 & 997 & 35.7 & 65.2 & 47.9 & 29.9 & 16.9 & 44.1 \\
\hline $\begin{array}{l}704^{\circ} \mathrm{C} \\
1000 \mathrm{hrs}\end{array}$ & 1351 & 1012 & 17.9 & 22.4 & 1051 & 845 & 40.2 & 75.5 & 5.7 & 36.1 & 2.5 & 37.7 \\
\hline$R_{T}$ & 0.92 & 0.84 & 0.76 & 0.57 & 0.89 & 0.85 & 1.13 & 1.16 & 0.12 & 1.21 & 0.15 & 0.86 \\
\hline \multicolumn{13}{|c|}{ WE91 $(0.006 \% \mathrm{C}+0.020 \% \mathrm{P}+0.010 \% \mathrm{~B})$} \\
\hline $\begin{array}{c}\text { As-Heat } \\
\text { Treated }\end{array}$ & 1493 & 1229 & 23.7 & 39.7 & 1187 & 1012 & 28.6 & 56.0 & 56.0 & 26.8 & 17.4 & 41.1 \\
\hline $\begin{array}{c}704^{\circ} \mathrm{C} / \\
1000 \mathrm{hrs}\end{array}$ & 1380 & 1055 & 18.5 & 26.3 & 1058 & 884 & 34.4 & 73.1 & 6.3 & 40.3 & 3.2 & 38.2 \\
\hline$R_{T}$ & 0.92 & 0.86 & 0.78 & 0.66 & 0.89 & 0.87 & 1.20 & 1.30 & 0.11 & 1.50 & 0.18 & 0.93 \\
\hline
\end{tabular}

Notes: 1. All samples heat treated:

$982^{\circ} \mathrm{C} \times 1 \mathrm{hr} . \mathrm{AC} .718^{\circ} \mathrm{C} \times 8$ hrs. $\mathrm{FC}$ at $55^{\circ} \mathrm{C} / \mathrm{hr}$ to $621^{\circ} \mathrm{C} \times 8 \mathrm{hrs} . . \mathrm{AC}$

2. Retention ratio $\mathrm{R}_{\mathrm{T}}$ of a specific property is the ratio of the value after to the value before $704^{\circ} \mathrm{C} / 1000 \mathrm{hr}$. thermal exposure.

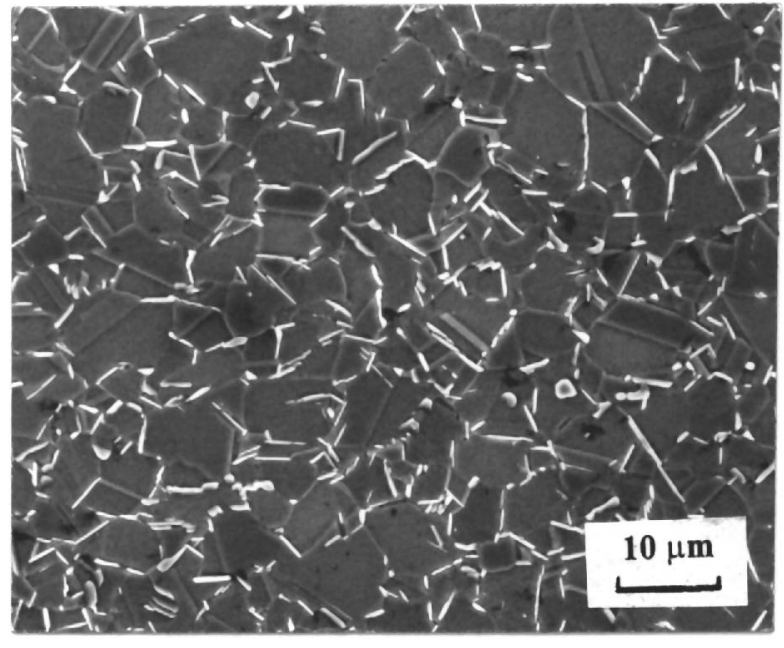

(a)

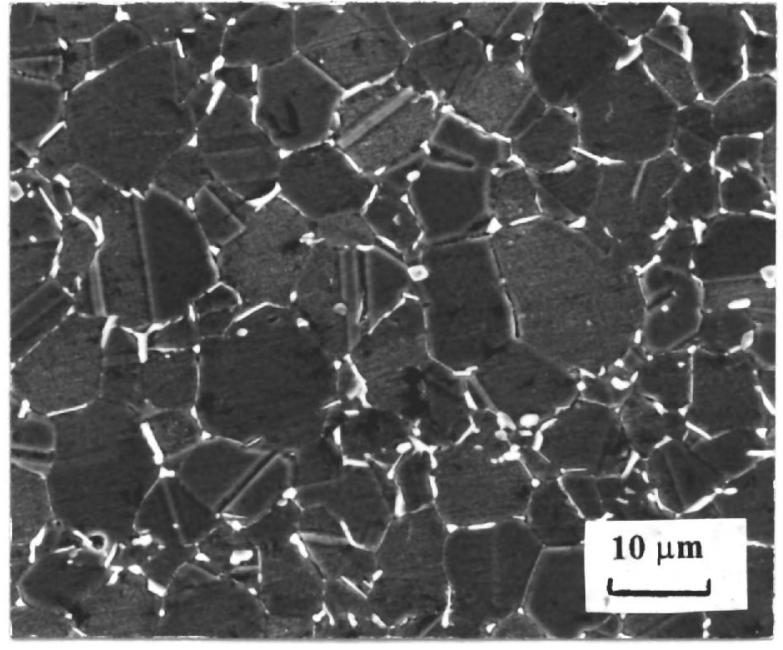

(b)

Figure 1: $\delta$-phase and grain structure in Standard 718 (a) and 718CM (b) subject to modified heat treatment. 
Table IV. Effect of $704^{\circ} \mathrm{C} / 1000 \mathrm{hr}$. Thermal Exposure on Mechanical Properties of $718 \mathrm{Ti} / \mathrm{Al}$ with Different $\mathrm{P}$ and $\mathrm{B}$ Contents

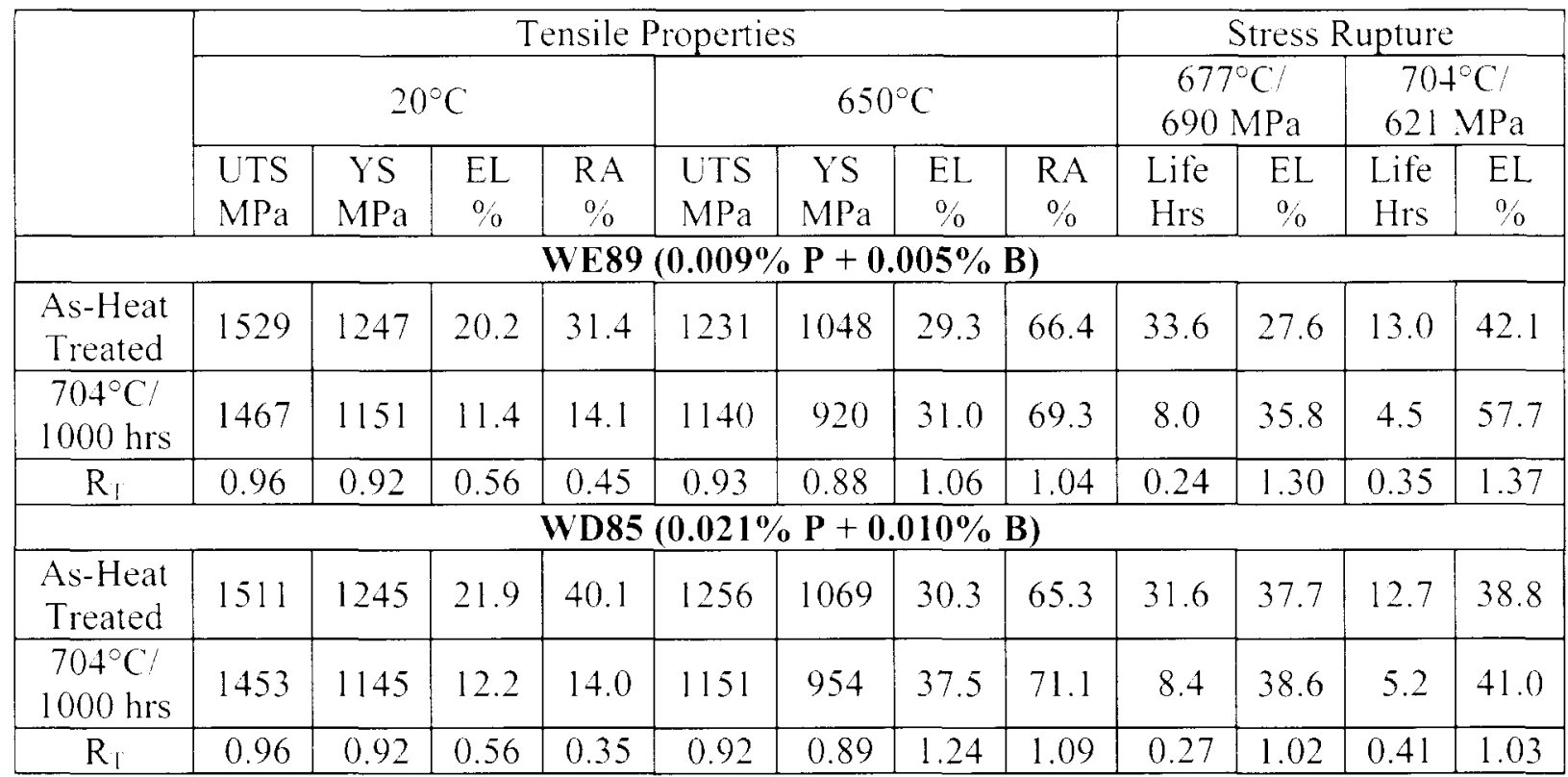

Notes: 1. All samples heat treated:

$982^{\circ} \mathrm{C} \times 1 \mathrm{hr} . . \mathrm{AC} .760^{\circ} \mathrm{C} \times 8 \mathrm{hrs} . . \mathrm{FC}$ at $55^{\circ} \mathrm{C} / \mathrm{hr}$ to $650^{\circ} \mathrm{C} \times 8 \mathrm{hrs} . . \mathrm{AC}$

2. Retention ratio $R_{T}$ of a specific property is the ratio of the value after to the value before $704^{\circ} \mathrm{C} / 1000 \mathrm{hr}$. thermal exposure.

Table V. Effect of $704^{\circ} \mathrm{C} / 1000 \mathrm{hr}$ Thermal Exposure on Mechanical Properties of Ticolloy with Different $P$ and $B$ Contents

\begin{tabular}{|c|c|c|c|c|c|c|c|c|c|c|c|c|}
\hline & \multicolumn{8}{|c|}{ Tensile Properties } & \multicolumn{4}{|c|}{ Stress Rupture } \\
\hline & \multicolumn{4}{|c|}{$20^{\circ} \mathrm{C}$} & \multicolumn{4}{|c|}{$650^{\circ} \mathrm{C}$} & \multicolumn{2}{|c|}{$\begin{array}{c}677^{\circ} \mathrm{Cl} \\
690 \mathrm{MPa} \\
\end{array}$} & \multicolumn{2}{|c|}{$\begin{array}{c}704^{\circ} \mathrm{C} / \\
621 \mathrm{MPa} \\
\end{array}$} \\
\hline & $\begin{array}{l}\text { UTS } \\
\mathrm{MPa} \\
\end{array}$ & $\begin{array}{c}\mathrm{YS} \\
\mathrm{MPa} \\
\end{array}$ & $\begin{array}{l}\text { EL } \\
\% \\
\end{array}$ & $\begin{array}{c}\text { RA } \\
\% \\
\end{array}$ & $\begin{array}{l}\text { UTS } \\
\mathrm{MPa} \\
\end{array}$ & $\begin{array}{c}\mathrm{YS} \\
\mathrm{MPa} \\
\end{array}$ & $\begin{array}{l}E L \\
\%\end{array}$ & $\begin{array}{c}\text { RA } \\
\%\end{array}$ & $\begin{array}{l}\text { Life } \\
\text { Hrs }\end{array}$ & $\begin{array}{c}\mathrm{EL} \\
\%\end{array}$ & $\begin{array}{l}\text { Life } \\
\text { Hrs }\end{array}$ & $\begin{array}{c}\mathrm{EL} \\
\% \\
\end{array}$ \\
\hline \multicolumn{13}{|c|}{ WE88 $(0.008 \% \mathrm{P}+0.005 \% \mathrm{~B})$} \\
\hline $\begin{array}{l}\text { As-Heat } \\
\text { Treated }\end{array}$ & 1526 & 1227 & 22.9 & 38.2 & 1244 & 1037 & 27.1 & 48.7 & 26.1 & 40.4 & 11.3 & 44.5 \\
\hline $\begin{array}{c}704^{\circ} \mathrm{C} / \\
1000 \mathrm{hrs}\end{array}$ & 1405 & 1065 & 9.0 & 9.6 & 1134 & 931 & 42.5 & 72.9 & 5.3 & 40.4 & 4.3 & 41.0 \\
\hline $\mathrm{R}_{\mathrm{I}}$ & 0.92 & 0.87 & 0.39 & 0.25 & 0.91 & 0.90 & 1.57 & 1.50 & 0.20 & 1.06 & 0.38 & 0.98 \\
\hline \multicolumn{13}{|c|}{ WD88 $(0.021 \% \mathrm{P}+0.011 \% \mathrm{~B})$} \\
\hline $\begin{array}{l}\text { As-Heat } \\
\text { Treated }\end{array}$ & 1520 & 1223 & 21.1 & 32.2 & 1222 & 1016 & 35.0 & 59.6 & 41.1 & 38.0 & 14.4 & 42.0 \\
\hline $\begin{array}{c}704^{\circ} \mathrm{Cl} \\
1000 \mathrm{hrs}\end{array}$ & 1431 & 1067 & 11.4 & 13.3 & 1093 & 864 & 41.5 & 73.2 & 6.8 & 40.8 & 4.9 & 33.8 \\
\hline $\mathrm{R}_{\mathrm{T}}$ & 0.94 & 0.87 & 0.54 & 0.41 & 0.89 & 0.85 & 1.19 & 1.23 & 0.17 & 1.01 & 0.34 & 0.76 \\
\hline
\end{tabular}

Notes: 1. All samples heat treated:

$982^{\circ} \mathrm{C} \times 1 \mathrm{hr} . \mathrm{AC} .760^{\circ} \mathrm{C} \times 8 \mathrm{hrs} . \mathrm{FC}$ at $55^{\circ} \mathrm{C} / \mathrm{hr}$ to $650^{\circ} \mathrm{C} \times 8 \mathrm{hrs} . . \mathrm{AC}$

2. Retention ratio $\mathrm{R}_{\mathrm{T}}$ of a specific property is the ratio of the value after to the value before $704^{\circ} \mathrm{C} / 1000 \mathrm{hr}$. thermal exposure. 
Table VI. Effect of $704^{\circ} \mathrm{C} / 1000$ hr Thermal Exposure on Mechanical Properties of $718 \mathrm{CM}$ with Different $P$ and $B$ Contents

\begin{tabular}{|c|c|c|c|c|c|c|c|c|c|c|c|c|}
\hline & \multicolumn{8}{|c|}{ Tensile Properties } & \multicolumn{4}{|c|}{ Stress Rupture } \\
\hline & \multicolumn{4}{|c|}{$20^{\circ} \mathrm{C}$} & \multicolumn{4}{|c|}{$650^{\circ} \mathrm{C}$} & \multicolumn{2}{|c|}{$\begin{array}{c}677^{\circ} \mathrm{C} \\
690 \mathrm{MPa}\end{array}$} & \multicolumn{2}{|c|}{$\begin{array}{l}704^{\circ} \mathrm{C} \\
621 \mathrm{MPa} \\
\end{array}$} \\
\hline & $\begin{array}{l}\text { UTS } \\
\mathrm{MPa}\end{array}$ & $\begin{array}{c}\mathrm{YS} \\
\mathrm{MPa}\end{array}$ & $\begin{array}{c}\text { EL } \\
\% \\
\end{array}$ & $\begin{array}{c}\mathrm{RA} \\
0 \% \\
\end{array}$ & $\begin{array}{l}\text { UTS } \\
\mathrm{MPa}\end{array}$ & $\begin{array}{c}\mathrm{YS} \\
\mathrm{MPa} \\
\end{array}$ & $\begin{array}{c}\text { EL } \\
\% \\
\end{array}$ & $\begin{array}{c}\text { RA } \\
\% \\
\end{array}$ & $\begin{array}{l}\text { Life } \\
\text { Hrs }\end{array}$ & $\begin{array}{c}\text { EL } \\
\% \\
\end{array}$ & $\begin{array}{l}\text { Life } \\
\text { Hrs }\end{array}$ & $\begin{array}{c}\text { EL } \\
0 \%\end{array}$ \\
\hline \multicolumn{13}{|c|}{ WG45 $(0.008 \% \mathrm{P}+0.005 \% \mathrm{~B})$} \\
\hline $\begin{array}{l}\text { As-Heat } \\
\text { Treated }\end{array}$ & 1469 & 1087 & 23.7 & 39.7 & 1194 & 907 & 19.3 & 23.2 & 23.1 & 13.7 & 11.0 & 19.1 \\
\hline $\begin{array}{c}704^{\circ} \mathrm{C} \\
1000 \mathrm{hrs}\end{array}$ & 1412 & 1023 & 18.4 & 24.4 & 1147 & 864 & 29.0 & 42.2 & 10.1 & 35.2 & 5.6 & 33.8 \\
\hline $\mathrm{R}_{\mathrm{T}}$ & 0.96 & 0.94 & 0.78 & 0.61 & 0.96 & 0.95 & 1.50 & 1.82 & 0.44 & 2.57 & 0.51 & 1.77 \\
\hline \multicolumn{13}{|c|}{ WD89 $(0.021 \% \mathrm{P}+0.010 \% \mathrm{~B})$} \\
\hline $\begin{array}{l}\text { As-Heat } \\
\text { Treated }\end{array}$ & 1503 & 1109 & 20.1 & 29.7 & 1173 & 922 & 35.0 & 65.9 & 64.6 & 28.4 & 13.7 & 37.7 \\
\hline $\begin{array}{c}704^{\circ} \mathrm{C} \\
1000 \mathrm{hrs}\end{array}$ & 1443 & 1020 & 11.7 & 14.3 & 1091 & 830 & 37.3 & 72.1 & 21.6 & 29.1 & 6.8 & 34.0 \\
\hline $\mathrm{R}_{\mathrm{T}}$ & 0.96 & 0.92 & 0.58 & 0.48 & 0.93 & 0.90 & 1.07 & 1.09 & 0.33 & 1.01 & 0.50 & 0.91 \\
\hline
\end{tabular}

Notes: 1. All samples heat treated:

$982^{\circ} \mathrm{C} \times 1$ hr.. AC

$850^{\circ} \mathrm{C} \times 1 / 2 \mathrm{hrs} . \mathrm{FC}$ at $200^{\circ} \mathrm{C} / \mathrm{hr}$ to $650^{\circ} \mathrm{C} \times 16 \mathrm{hrs} . . \mathrm{AC}$

2. Retention ratio $R_{T}$ of a specific property is the ratio of the value after to the value before $704^{\circ} \mathrm{C} / 1000 \mathrm{hr}$. thermal exposure.

\section{$\underline{\text { Microstructures }}$}

Chemistry modifications made in this study had no significant effect on grain size. Results varied within a very narrow range and measured about $8-10 \mu \mathrm{m}$ after the standard heat treatment and 10-12 $\mu \mathrm{m}$ after modified heat treatments. Generally, $718 \mathrm{CM}$ had a slightly coarser grain size than the other three groups. The slightly coarser grain size in $718 \mathrm{CM}$ may relate to the difference in quantity of $\delta$ phase particles. The volume fraction of $\delta$ phase particles was slightly reduced in all alloys with modified $\mathrm{Al}$, Ti and $\mathrm{Nb}$ contents, but it was noticeably lower in $718 \mathrm{CM}$ (Figure 1). The size and morphology of $\delta$ phase particles were not changed much by either $\mathrm{P}$ and $\mathrm{B}$ or $\mathrm{Al}, \mathrm{Ti}$ and $\mathrm{Nb}$ modification.

As reported previously [14], three microstructural changes occurred in alloy 718 during long time heating at $704^{\circ} \mathrm{C}$ : growth of precipitates $\gamma^{\circ}$ and $\gamma^{\prime \prime}$. formation of a $\gamma^{\prime \prime}$-depletion zone at grain boundaries and formation of Nb-containing blocky particles. The same changes occurred in all test alloys in this study, but the degree of changes did vary in different alloys. These differences can be seen from Figures 2 and 3 . Figure 2 shows the microstructures of alloy 718 after $704^{\circ} \mathrm{C} \times 1000$ hrs. thermal exposure. A precipitate depleted zone can be clearly seen around needle-like $\delta$ phase particles and newly formed blocky particles. Remaining precipitates barely visible in the depleted zone were predominantly spherical $\gamma$ particles. but the density was low. Both $\gamma^{\prime}$ and $\gamma^{\prime \prime}$ particles had grown to a size distinguishable at $3000 \mathrm{X}$. and it seemed that $P$ and $B$ had no noticeable effect on the size of these particles. The blocky particles newly formed during heating had an average $\mathrm{Nb}$ content lower than that of $\delta$ phase, and were probably 
in the process of transforming to $\delta$ phase. In comparison with microstructures of alloy 718 shown in Figures 2 (a) and (b). several differences were noticed in $718 \mathrm{CM}$ as illustrated in Figure 3. It can be seen from Figure 3 that the size of precipitate particles was smaller for alloy $718 \mathrm{CM}$, indicating that $\mathrm{Al}$, Ti and $\mathrm{Nb}$ modification retarded precipitate growth. The quantity of $\gamma$ " particles was reduced and quantity of spherical $\gamma$ ' particles increased. Those observations are consistent with the results reported in many references. The alloys with modified strengthening elements and standard $\mathrm{P}$ and $\mathrm{B}$ contents actually showed a wider $\gamma \ddot{ }$ depleted zone. but a higher density of $\gamma^{\prime}$ particles. Increasing $\mathrm{P}$ and $\mathrm{B}$ significantly reduced the width of $\gamma^{\prime \prime}$ depleted zone in alloy $718 \mathrm{CM}$ as clearly seen in Figures 3 (a) and (c) at lower magnification. The same phenomenon existed in other $\mathrm{Al}$ and $\mathrm{Ti}$ modified alloys of this study, but to a much lesser degree. This may imply that increased $\mathrm{P}$ and B might stabilize $\gamma^{\prime \prime}$ particles. No noticeable effect of $\mathrm{P}$ and $\mathrm{B}$ modification on $\gamma^{\circ}$ particles was observed. More work is necessary to fully characterize the changes caused by modifying minor and strengthening elements in alloy 718 .

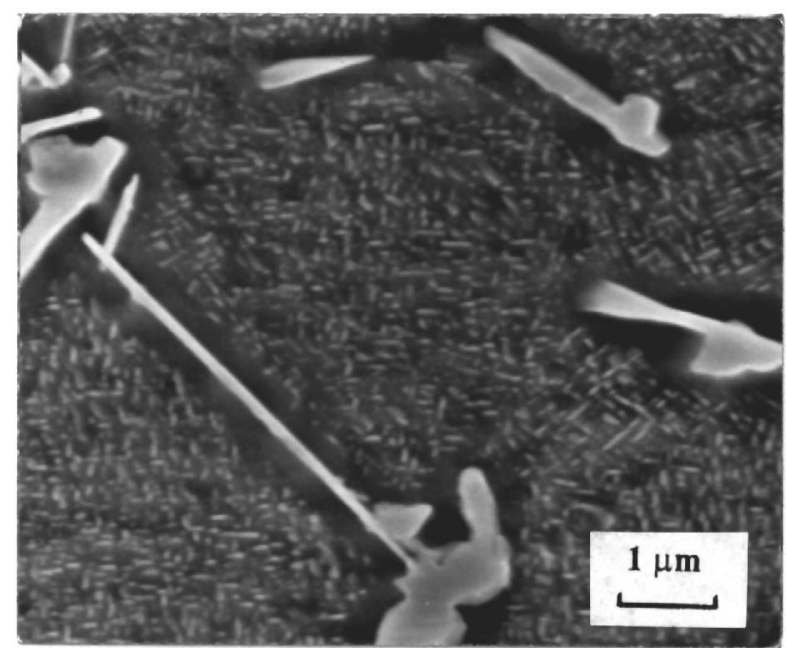

(a)

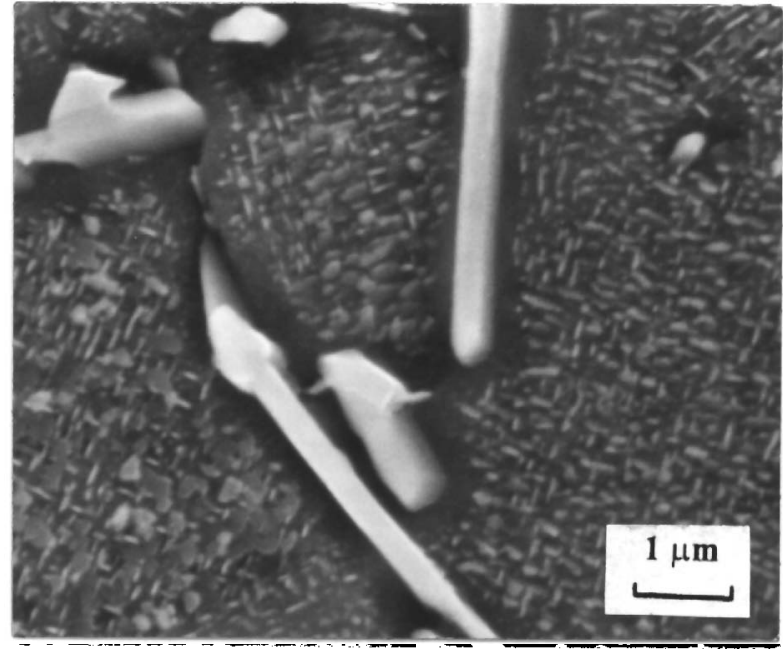

(b)

Figure 2: Microstructures of Standard 718 after $704^{\circ} \mathrm{C} \times 1000$ hrs. thermal exposure (a) $0.008 \mathrm{P}$. $0.005 \mathrm{~B}$ (b) $0.020 \mathrm{P}, 0.010 \mathrm{~B}$.

\section{Discussion}

This study shows that increasing $\mathrm{P}$ and $\mathrm{B}$ improved stress rupture properties of both standard and modified alloy 718 , but the improvement diminished with increasing test temperature and especially after long time heating at high temperature. This can be clearly seen in Figure 4 where the ratios of stress rupture life at increased $\mathrm{P}$ and $\mathrm{B}$ levels to that at standard $\mathrm{P}$ and $\mathrm{B}$ levels $\left(R_{P}\right)$ are plotted by test alloys. Except for $718 \mathrm{Ti} / \mathrm{Al}$, the ratios were all greater than 1.0 , showing that stress rupture life improved by increasing $\mathrm{P}$ and $\mathrm{B}$, and decreased with increasing test temperature and after 1000 hrs. thermal exposure at $704^{\circ} \mathrm{C}$. A similar trend was observed in previous work with standard 718 [14] and was explained in terms of the interaction between $P$ and $\mathrm{B}$ atoms and $\gamma$ " particles. It was suggested that the strengthening effect of $\mathrm{P}$ and $\mathrm{B}$ additions might be partially associated with $\gamma$ " particles and would be reduced with a loss of the strengthening effect of $\gamma^{\prime \prime}$ and with a reduction in its volume fraction. Thus the reduced effectiveness of $y^{\prime \prime}$ strengthening at higher test temperatures and the formation of $\gamma^{\prime \prime}$-depleted zone after long time heating would lead to a reduction in the strengthening effect from $P$ and $B$ modification. This postulation is supported by this study. The higher $R_{P}$ ratios observed in $718 \mathrm{CM}$ at $677^{\circ} \mathrm{C} / 690 \mathrm{MPa}$ can also be explained by this effect. As shown in Figure 3. a smaller $\gamma$ "- depleted zone formed after thermal exposure in $718 \mathrm{CM}$ with increased $\mathrm{P}$ and $\mathrm{B}$ contents: thus it can be assumed, maintaining more of the strengthening effect of $\mathrm{P}$ and $\mathrm{B}$ modification. 


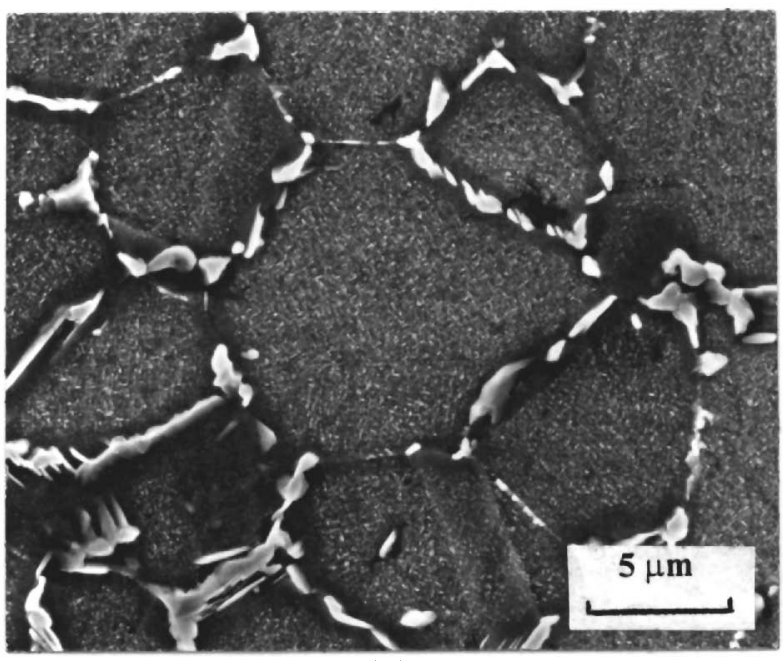

(a)

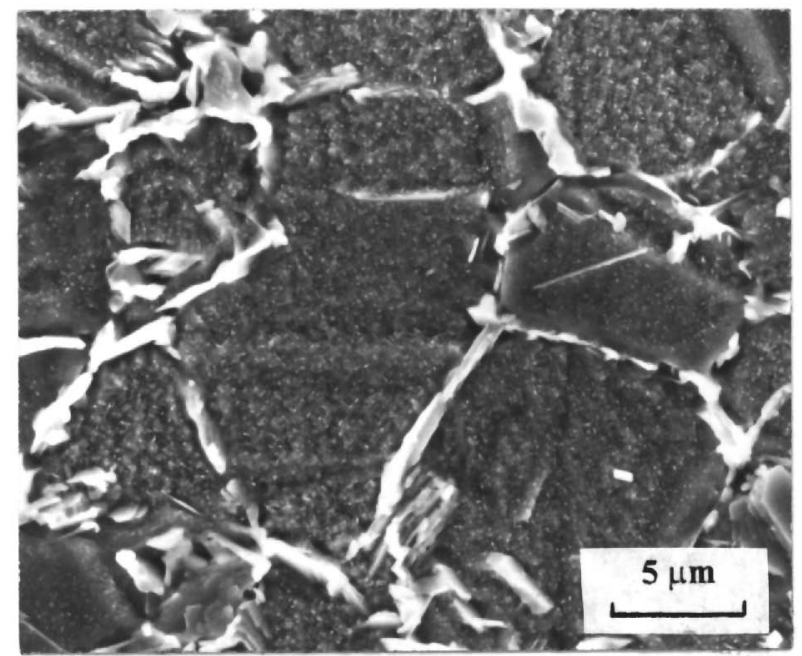

(c)

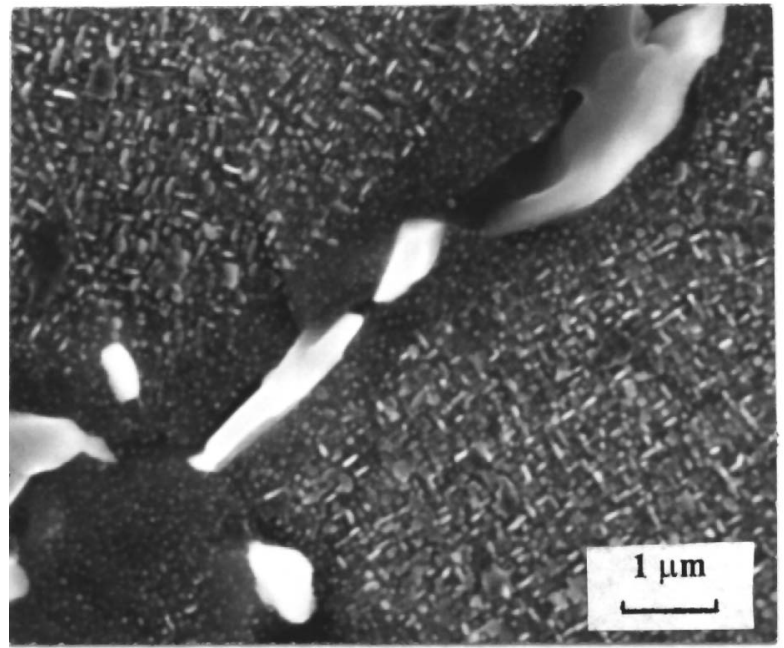

(b)

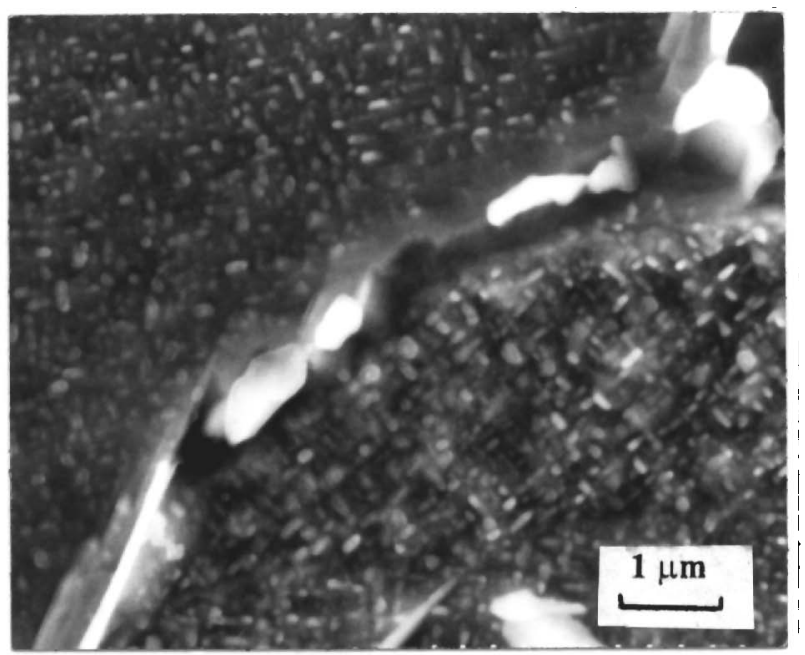

(d)

Figure 3: Microstructure of Alloy $718 \mathrm{CM}$ atter $704^{\circ} \mathrm{C} \times 1000$ hrs. thermal exposure (a) and (b) at standard P and B levels, (c) and (d) at increased P and B levels.

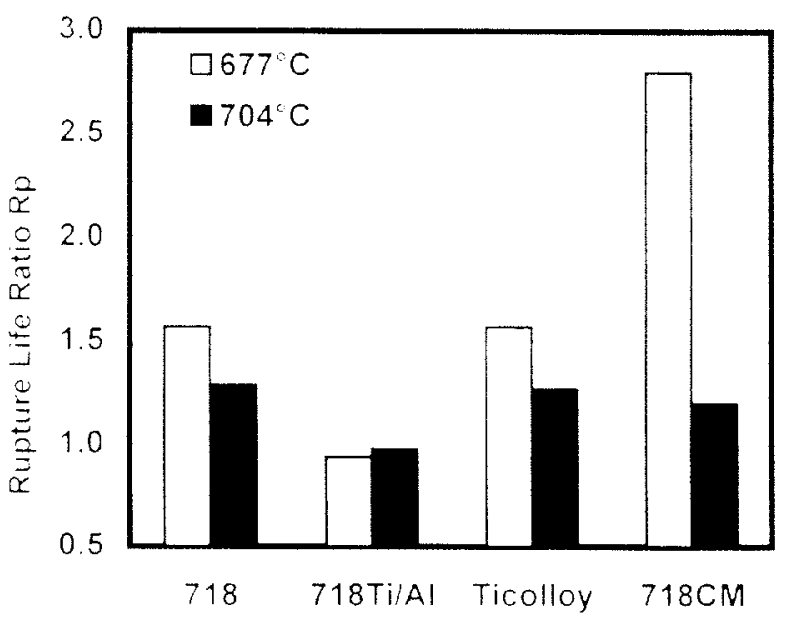

(a)

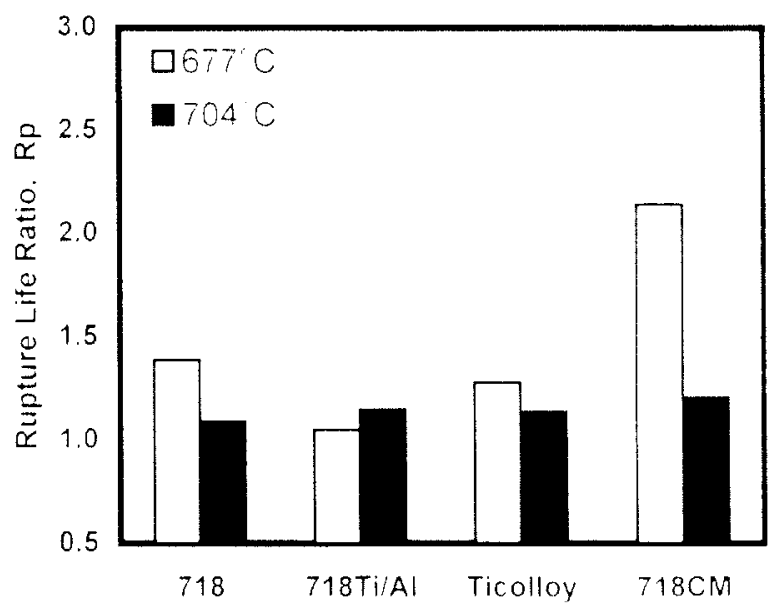

(b)

Figure 4: Ratio of stress rupture life at increased $\mathrm{P}$ and $\mathrm{B}$ levels to that at standard $\mathrm{P}$ and $\mathrm{B}$ levels (a) as-heated and (b) after $704^{\circ} \mathrm{C} \times 1000 \mathrm{hrs}$. thermal exposure. 
The increase in stress rupture life by $\mathrm{Al}, \mathrm{Ti}$ and $\mathrm{Nb}$ modifications in the standard heat treatment condition (Table II) was most likely due to $y^{*}$ particles. since all of the modifications used have an increased volume fraction of $y^{*}$.

The reduction in stress rupture life for the $\mathrm{Al}$, Ti and $\mathrm{Nb}$ modified alloys in the modified heat treat condition was most likely caused by a change in the size and relative quantity of $y^{*}$ and $y^{*}$ particles; since the purpose of the modified aging treatments was to obtain more stable precipitates to maximize properties at higher temperatures. This was especially true for $718 \mathrm{CM}$ where a stable, compact morphology of $y^{\prime} / y^{\prime \prime}$ particles forms from the high aging temperatures. This heat treatment caused the growth of precipitates and the reduction in $y^{\prime \prime}$ particles. resulting in lower strength and rupture life as heat treated. Thermal stability, however, was increased due to this special morphology and increased quantity of $y^{*}$ particles. as shown by the higher retention ratio for both tensile strength and stress rupture life (Tables III and VI).

The increase in thermal stability achieved by strengthening element modification created the possibility of maintaining the improvement in stress rupture properties due to $\mathrm{P}$ and $\mathrm{B}$ modification to higher temperatures. Alloy modification in $718 \mathrm{CM}$ with high $\mathrm{P}$ and $\mathrm{B}$ contents produced the best results in this regard. No attempt was made to quantitatively evaluate the improvement in temperature capability of such modifications, but it was moderate and probably not greater than $25^{\circ} \mathrm{C}$. However. further improvements may be possible.

\section{Conclusions}

1. $\mathrm{Al}, \mathrm{Ti}$ and $\mathrm{Nb}$ modifications suggested in the literature moderately improved the stress rupture life of alloy 718 in the standard heat treatment condition. Modified heat treatment conditions recommended to give a more stable precipitation morphology lowered the rupture life.

2. $\mathrm{Al}, \mathrm{Ti}$ and $\mathrm{Nb}$ modifications appeared to increase the thermal stability of alloy 718 , as shown by higher stress rupture life after $704^{\circ} \mathrm{C}$ x 1000 hrs. thermal exposure. Extremely short lives and small differences in the absolute numbers suggest additional testing on the issue of thermal stability is necessary.

3. Increased P and B levels significantly improved stress rupture life of standard and modified alloy 718. The improvement diminished with increasing test temperature and after long time heating at high temperature. The retention ratio of stress rupture life was basically the same for standard and $\mathrm{P}$ and $\mathrm{B}$ modified alloys, indicating that $\mathrm{P}$ and $\mathrm{B}$ modification did not improve thermal stability.

4. Combining $\mathrm{Al}, \mathrm{Ti}$ and $\mathrm{Nb}$ and $\mathrm{P}$ and $\mathrm{B}$ modifications further improved the stress rupture life of alloy 718 and more importantly maintained the improvement from $\mathrm{P}$ and $\mathrm{B}$ modification to higher temperature. The best results were achieved from alloy $718 \mathrm{CM}$ with increased $\mathrm{P}$ and $\mathrm{B}$ levels.

\section{References}

1. W.D. Cao and R.L. Kennedy, Superalloys 718, 625, 706 and Various Derivatives, ed. E.A. Loria, (TMS 1994), 463-477.

2. W.D. Cao and R.L. Kennedy, Superalloys 1996. ed. R.D. Kissinger et al., (TMS 1996), $589-597$.

3. R.L. Kennedy, W.D. Cao and W.M. Thomas, Advanced Materials \& Processes, Vol. 150. (1996). No. 3, 33-34. 
4. W.D. Cao and R.L. Kennedy, Superalloys 718, 625.706 and Various Derivatives, ed. E.A. Loria, (TMS 1997), 511-520.

5. W.D. Cao and R.L. Kennedy, Superalloys 2000, ed. R.D. Kissinger et al.. (T.MS 1996), $589-597$.

6. X. Xie et al., Superalloys 1996, ed. R.D. Kissinger et al., (TMS 1996), 599-606.

7. X. Xie et al., Superalloys 718, 625, 706 and Various Derivatives, ed. E.A. Loria, (TMS 1997). $531-542$

8. W.R. Sun et al., Hu, Metall. Trans. A, Vol. 28A, (1997), 649-654.

9. S.R. Guo et al, Superalloys 718,625, 706 and Various Derivatives, ed. E.A. Loria. (TMS 1997), $521-530$.

10. W.R. Sun et al., Mater. Sci. Eng. A, Vol. 247. (1998), 173-179.

11. X. Liu, et al., Mater. Sci. Eng. A, Vol. 270, (1999), 190-196.

12. C.G. McKamey, et al., Scripta Materialia, Vol. 38, (1998), 485-491.

13. H. Song, S. Guo and Z. Hu, Scripta Materialia, Vol. 41, (1999), 215-219.

14. W.D. Cao and R.L. Kennedy, "Thermal Stability of 718 and Allvac 718-ER "Alloys." to be published in Superalloys 718,625, 706 and Various Derivatives, ed. E.A. Loria, (TMS, 2001).

15. J.P. Collier, A.O. Selius and J.K. Tien, Superalloys 1988, ed. by S. Reichman et al., (TMS, 1988), 43-52.

16. J.P. Collier, et al, Metall. Trans. A, (1988), Vol. 19A, 1657-1666.

17. J.K. Tien, et al, Proceedings of the 1990 High Temperature Materials for Power Engineering Conference, ed. E.B. Bachelet, et al. (Kluwer Academic Publishers, 1990), 1341-1356.

18. J.A. Manriquez, et al., Superalloys 1992, ed. S. D. Antolovich, et al., (TMS, 1992), 507-516.

19. R. Cozar and A. Pineau, Metall. Trans., Vol. 4, (1973), 47-59.

20. E. Andrieu, R. Cozar and A. Pineau. Superalloy 718 - Metallurgy and Applications, ed. E.A. Loria, (TMS, 1989), 241-256.

21. E. Andrieu. et al., Superalloys 718, 625, 706 and Various Derivatives, ed. E.A. Loria, (TMS. 1994), 695-710.

22. E.C. Guo, F.Q. Xu and E.A. Loria, Superalloy 718 - Metallurgy and Applications. ed. E.A. Loria, (TMS, 1989), 567-576.

23. E.C. Guo, F.Q. Xu and E.A. Loria, Superalloys 718, 625, 706 and Various Derivatives, ed. E.A. Loria, (TMS, 1991), 389-396.

24. E.C. Guo, F.Q. Xu and E.A. Loria, Superalloys 718, 625, 706 and Various Derivatives, ed. E.A. Loria, (TMS, 1991), 397-408.

25. X. Xie, et al, Superalloys 718, 625, 706 and Various Derivatives, ed. E.A. Loria, (TMS, 1994), $711-720$.

26. E.C. Guo, F.Q. Xu and E.A. Loria. Superalloys 718, 625, 706 and Various Derivatives, ed. E.A. Loria, (TMS, 1994), 720-734. 